\title{
Effect of Fire Intensity on Non-Native Plant Species Community in a Canarian Pine Forest Three and Eleven Years After Fire
}

\author{
C. García-Domínguez ${ }^{*}$ and J.M. Fernández-Palacios
}

Departamento de Ecología, Facultad de Biología, Universidad de La Laguna, La Laguna 38206, España

\begin{abstract}
The invasion of non-native plant species is one of the greatest threats to natural ecosystems, and oceanic islands are especially susceptible to this threat. Fire, as a disturbance factor, has been found to promote non-native species invasion and fire intensity is one of the variables determining the severity of invasions. This study was designed to determine the impact of non-native species in the Tenerife pine forest understory on the island of Tenerife, Canary Islands, Spain, and how they are affected by low and high intensity wildfire. We resampled in 2006 the plots set for a previous study in 1998 within the area affected by a wildfire in June 1995. Six control plots, nine low-severity burned plots and twelve high-severity burned plots were sampled three and eleven years after fire. Native species cover increased in high severely burned plots with respect to control plots. It also increased in low and high severely burned plots from 1998 to 2006. No differences were found for non-native cover and richness between fire intensities or in time. Results suggest that some of the native understory plant species are adapted to high intensity fire and respond by increasing their cover after fire to the detriment of non-native species. Forest management with prescribed fire may not increase nonnative species invasion as has occurred in other ecosystems.
\end{abstract}

Keywords: Non-native species, wildfire, Pinus canariensis, understory.

\section{INTRODUCTION}

Invasion of non-native plant species is considered one of the greatest threats to natural ecosystems worldwide [1]. Oceanic islands are especially susceptible to invasions as their ecosystems have special characteristics derived from isolated evolution. They have a reduced number of species, which means low competition, absence of large herbivores, absence of diseases and disharmonic flora and fauna [2].

The loss of the existing plant biomass due to a disturbance is the most important factor inducing non-native plant invasion in natural or seminatural ecosystems [3-6], but the presence of non-native species propagules [7] and the ratio of native-non-native propagules $[8,9]$ will be important factors determining the invasion rate after a disturbance. Large wildfires can eliminate all the vegetation cover and may alter plant community composition by providing ideal habitats for non-native species [10]. Many studies have found an increase in abundance and richness of understory plant species after fire mostly due to ruderal species $[11,12]$. But these species were native in some cases $[13,14]$ and non-native in others [15-18].

Fire severity affects the survival and recovery of vegetation $[19,20]$ and non-native species invasion can respond in different ways to different fire severities $[15,10$, 21]. Adaptation to fire, climatic conditions after fire and post fire management also have an influence on non-native species invasion after wildfire [22]. Even in communities

*Address correspondence to this author at the Departamento de Ecología, Facultad de Biología, Universidad de La Laguna, La Laguna 38206, España; Tel: +34922318363; Fax: +34922318311; E-mail: celiagd@ull.es adapted to high severity fire, non-native species may enter the community post fire and reduce survival of pre-fire vegetation [8].

In the Canary Islands, prescribed burnings in pine forest have been applied during the last few years to reduce fuel amounts, but the possible effects of this management on nonnative plants invasion has not been studied. Although the present study was conducted in an area burned by a wildfire, results after low-intensity wildfire may be useful to predict what would happen after a low-intensity prescribed burn.

Non-native species on Tenerife Island in 2005 made up $11 \%$ of the total species on the island [23]. The Canary Islands are part of one of the 25 hotspots of biodiversity in the world and currently, non-native species are the primary threat to the 100 most threatened native species [24]. Although the most dangerous non-native species are all vertebrates [25], 46\% (79 species) of the total non-native species in Tenerife are plants [23].

The pine forest in Tenerife is not one of the ecosystems most affected by non-native plant species at the moment, but two of the 100 most invasive species in Macaronesia are common there: Eucalyptus globulus and Eschscholzia californica [26]. Neither of these species were present at the study plots.

For this manuscript, we used data from a previous study about plant species composition three years after fire, which did not take in account species origin [12]. We resampled the same plots eleven years after fire, to have longer term data and to be able to compare both sampling periods.

The aim of this study was to compare richness and cover of native and non-native species found in three different wildfire intensities and how this chages in time. Differences 
in species composition were tested as well. The study hypoteses were: 1) General species cover and richness will increase after fire, mostly after high intensity fire; 2) This effect will be transitory and pre-fire conditions will recover over time; 3) Increase in species cover and richness after fire will be mostly due to non-native species; 4) Fire severity will have an effect on species composition and the ratio nativenon-native species.

\section{MATERIALS AND METHODOLOGY}

\section{Study Site}

The present study was conducted in the Corona Forestal National Park $\left(28^{\circ} 19^{\prime} \mathrm{N}, 16^{\circ} 34^{\prime} \mathrm{W}\right)$ in Tenerife, which was extensively affected by a wildfire in June 1995. The study sites were planted with $P$. canariensis during the 1940s and 1950s [27] as part of a reforestation program. At present, mean pine density of the studied sites is 875 trees/ha at the windward site (N-NE) and 1140 trees/ha at the leeward site (S-SW). Mean DBH and height are $84 \mathrm{~cm}$ and $20 \mathrm{~m}$ at windward and $74 \mathrm{~cm}$ and $17 \mathrm{~m}$ at leeward site, with a poor to absent regeneration.

Understory composition and structure of the Canarian pine forest maintain some differences depending on aspect. Due to moisture, the windward side has a more developed understory, which is dominated by Erica arborea and Adenocarpus viscosus. The leeward side usually has more open canopy, with less understory density, dominated by $A$. viscosus and Chamaecytisus proliferus.

Mean annual precipitation of the area is $600 \mathrm{~mm}$, but can be twice this amount if fog drip is considered [28]. Mean annual temperature is $11^{\circ} \mathrm{C}$ with $8-10^{\circ} \mathrm{C}$ between maximum and minimum day temperature and minimal annual fluctuation.

Additional information about the area and species is described by Ceballos and Ortuño [29], Blanco et al. [30] del Arco Aguilar et al. [27], Fernández-Palacios [31] and Arévalo et al. [12]. Nomenclature follows the check-list of Izquierdo et al. [32]. Species origins were taken from the same book. Only "definite" native and "probable" native species were marked as native species.

\section{Sampling Design}

Sampling design was performed by Arévalo et al. for a previous study [12]. Two sites were selected for this study, one facing N-NE (windward) and the second one facing SSO (leeward). Fifteen $10 \times 10 \mathrm{~m}$ plots were established at the windward site and twelve at the leeward site, affected by different fire severities. Three types of plots were differentiated as a function of the scorch height: control plots (C: not burnt), low-severity burned plots (L: surface fire) and high-severity burned plots (H: canopy largely or completely consumed). At the windward site three $\mathrm{C}$, six $\mathrm{L}$ and six $\mathrm{H}$ plots were established while at the leeward site, three $\mathrm{C}$, six $\mathrm{L}$ and three $\mathrm{H}$ plots were established. Due to the irregular effect of fire in the forest, plots could not be randomly set, but deliberately choosing areas were fire had the desired intensity.

Cover of all the understory species in each plot was estimated and noted as a cover category based on the following scale: 1 : traces; $2:<1 \% ; 3: 1-2 \% ; 4: 2-5 \% ; 5: 5-$
10\%; 6: 10-25\%; 7: 25-50\%; 8: 50-75\%; 9: 75\%-100\%. Elevation, slope, canopy cover, litter, bare soil, and rock cover were also measured on each plot. Sampling was conducted three years after the fire by the cited authors [12]. Eleven years after fire, we resampled the same plots and classified the data from both samplings into native and nonnative species.

\section{Statistical Analysis}

Species cover categories were converted back into percentages (midpoint of each category) for the analyses. After confirming the lack of a normal distribution of the data, we performed a Kruskal-Wallis test to see if there were differences between fire intensities for cover and richness of total understory vegetation, native, and non-native species separately. In the cases where differences were found, we used a Mann-Whitney $U$ test to know between which treatments were the differences. To test for changes over time in cover and richness, we used a Wilcoxon test for each fire intensity category separately, comparing results three years after fire with results eleven years after fire. We used a nonparametric test for the same reasons mentioned above. Both analyses were performed using the SPSS statistical package [33] with $\alpha=0.05$.

We used a Detrended Correspondence Analysis (DCA) [34] to show differences in species composition among all 27 plots. This indirect analysis helps to reveal environmental variables not included in the sampling, as it shows complete variation in species composition. Testing for Pearson correlation among samples coordinates on each axis and fire intensity, we can know if fire intensity is the variable explaining the species composition variation. We performed multivariate analysis with the CANOCO package [35].

\section{RESULTS}

Environmental variables of the plots at the two sites showed some differences in elevation and slope (Table 1). This is a consequence of the irregular intensity of fire within the affected area, which made necessary the subjective method of selecting plots. These variables were included as covariables for the multivariate analyses. Canopy cover was lower in high severely burned plots than in the other plots three years after fire, but canopy, soil and rock cover were not used as covariables for the analyses, as they can be directly related to fire intensity and we do not want to eliminate the variability created by these variables.

A total of 46 species were recorded in the understory community. 24 of them were native species, 16 were nonnative and 6 could not be completely identified. All nonnative species were theropyte and hemicryptophyte, while native species also included some nanophanerophytes and chamaephytes within the most common species.

Mean total understory vegetation cover was the highest in severely burned plots three and eleven years after fire (Table 2 and Fig. 1). Native species cover and richness were always higher than non-native species for all treatments (Table 2 and Fig. 1), but both were highly variable within fire intensities (Table 2), which makes difficult to find statistical differences. No statistical differences were found in total and non-native species cover and richness between different fire intensities in either year (Table 3). However, 
native species cover and total richness were significantly higher in high-intensity fire plots than in low-intensity fire plots three years after fire (Table 3). Two native shrub species (Adenocarpus viscosus and Chamaecytisus proliferus) were mostly responsible for this cover increase.

Table 1. Environmental Plots Characteristics Three Years After fire. Mean Percentage of Rock Cover, Bare Soil Cover and Canopy Cover. Mean Altitude and Slope. Data Eleven Years After Fire were Very Similar, Only High-Intensity Fire Plots' Canopy Cover Increased

\begin{tabular}{|c|c|c|c|c|c|}
\hline $\begin{array}{c}\text { Fire } \\
\text { Intensity }\end{array}$ & $\begin{array}{c}\text { Rock } \\
(\%)\end{array}$ & $\begin{array}{c}\text { Soil } \\
\mathbf{( \% )}\end{array}$ & $\begin{array}{c}\text { Canopy } \\
\mathbf{( \% )}\end{array}$ & $\begin{array}{c}\text { Elevation } \\
(\mathbf{m})\end{array}$ & $\begin{array}{c}\text { Slope } \\
\mathbf{( \% )}\end{array}$ \\
\hline \hline \multicolumn{5}{|l}{ Windward Site } \\
\hline control & 3.3 & 2.3 & 86.7 & 1418.3 & 80 \\
\hline low & 3.7 & 1.8 & 82.4 & 1435.0 & 70 \\
\hline high & 4.7 & 1.7 & 65.4 & 1410.0 & 70 \\
\hline Leeward Site & & & & \\
\hline control & 4.3 & 1.0 & 62.9 & 1531.7 & 100 \\
\hline low & 4.3 & 1.0 & 65.0 & 1481.0 & 95 \\
\hline high & 4.7 & 1.3 & 60.6 & 1485.0 & 85 \\
\hline
\end{tabular}

Table 2. Mean and Standard Deviation (in Brackets) of Richness and Cover Percentage for Each Treatment. Years After Fire are in Brackets

\begin{tabular}{|c|c|c|c|c|c|c|c|}
\hline & & $\begin{array}{c}\text { Total } \\
\text { (3) }\end{array}$ & $\begin{array}{l}\text { Nat. } \\
\text { (3) }\end{array}$ & $\begin{array}{l}\text { N-nat. } \\
\text { (3) }\end{array}$ & $\begin{array}{l}\text { Total } \\
\text { (11) }\end{array}$ & $\begin{array}{l}\text { Nat. } \\
\text { (11) }\end{array}$ & $\begin{array}{c}\text { N-nat. } \\
\text { (11) }\end{array}$ \\
\hline \multirow{2}{*}{ Control } & Richness & $\begin{array}{c}5.3 \\
(3.5)\end{array}$ & $\begin{array}{c}3.5 \\
(2.3)\end{array}$ & $\begin{array}{c}1.8 \\
(1.5)\end{array}$ & $\begin{array}{c}5.8 \\
(3.1)\end{array}$ & $\begin{array}{c}4 \\
(2.5)\end{array}$ & $\begin{array}{l}1.8 \\
(1)\end{array}$ \\
\hline & Cover & $\begin{array}{c}11.1 \\
(14.7)\end{array}$ & $\begin{array}{c}10.4 \\
(14.7)\end{array}$ & $\begin{array}{c}0.7 \\
(0.7)\end{array}$ & $\begin{array}{c}37.4 \\
(27.1)\end{array}$ & $\begin{array}{c}36.4 \\
(27.3)\end{array}$ & $\begin{array}{c}1 \\
(0.7)\end{array}$ \\
\hline \multirow{2}{*}{$\begin{array}{c}\text { Low- } \\
\text { Intensity }\end{array}$} & Richness & $\begin{array}{l}4.9 \\
(2)\end{array}$ & $\begin{array}{l}3.1 \\
(1.1)\end{array}$ & $\begin{array}{l}1.8 \\
(1.3)\end{array}$ & $\begin{array}{c}5 \\
(3.2)\end{array}$ & $\begin{array}{l}3.3 \\
(2)\end{array}$ & $\begin{array}{l}1.7 \\
(1.7)\end{array}$ \\
\hline & Cover & $\begin{array}{c}7.6 \\
(12.3)\end{array}$ & $\begin{array}{c}7 \\
(12.3)\end{array}$ & $\begin{array}{c}0.6 \\
(0.5)\end{array}$ & $\begin{array}{c}36.4 \\
(33.7)\end{array}$ & $\begin{array}{l}34.8 \\
(33)\end{array}$ & $\begin{array}{l}1.7 \\
(2.6)\end{array}$ \\
\hline \multirow{2}{*}{$\begin{array}{l}\text { High- } \\
\text { Intensity }\end{array}$} & Richness & $\begin{array}{l}8.1 \\
(3)\end{array}$ & $\begin{array}{c}5.1 \\
(1.8)\end{array}$ & $\begin{array}{c}3 \\
(1.5)\end{array}$ & $\begin{array}{c}5.7 \\
(3.4)\end{array}$ & $\begin{array}{c}4.3 \\
(2.2)\end{array}$ & $\begin{array}{l}1.3 \\
(1.6)\end{array}$ \\
\hline & Cover & $\begin{array}{c}27 \\
(18.9)\end{array}$ & $\begin{array}{c}26.2 \\
(18.9)\end{array}$ & $\begin{array}{c}0.8 \\
(0.6)\end{array}$ & $\begin{array}{c}73.8 \\
(56.1)\end{array}$ & $\begin{array}{c}72.3 \\
(54.7)\end{array}$ & $\begin{array}{l}1.5 \\
(3.3)\end{array}$ \\
\hline
\end{tabular}

Nat.: native species; N-nat.: non-native species.

With regard to changes on time, total and native species cover in low- and high-intensity fire plots increased significantly between 1998 and 2007 (Tables 2 and 4). We found no differences in non-native species cover or richness between three and eleven years after fire for any of the fire intensities (Table 4).

DCA revealed aspect to be the most important factor determining understory species composition (Figs. 2, 3), masking a possible effect of fire intensity. Both native and non-native species composition were different in windward and leeward plots. Three years after fire (Fig. 2), most nonnative species were associated with the windward site, where humidity stress is lower than at the leeward site. Non-native graminoids, Galium scabrum and Origanum vulgare were associated with control windward plots while Urospermum picrioides, Vicia sp. and Sonchus oleraceus were more common in burned plots. Briza maxima and Galium aparine were found in both windward and leeward burnt plots, while species of the genus Geranium were indicative of leeward burnt plots.
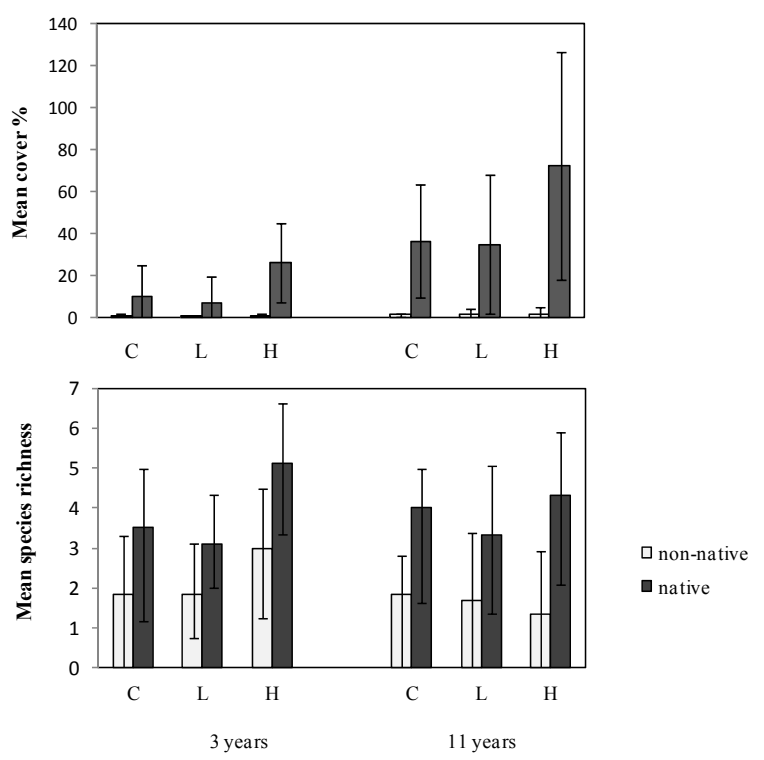

Fig. (1). Mean and standard deviation of native and non-native species cover and richness percentage, three and eleven years after fire. C: control; L: low-intensity fire; H: high-intensity fire.

Table 3. Number of Samples (n) Statistical Value $\left(X^{2}\right)$ and Significance (sig) for Kruskal-Wallis Tests

\begin{tabular}{|c|c|c|c|c|c|c|}
\hline & \multicolumn{3}{|c|}{ 3 Years } & \multicolumn{3}{c|}{ 11 Years } \\
\cline { 2 - 7 } & $\mathbf{n}$ & $\mathbf{X}^{\mathbf{2}}$ & $\mathbf{s i g}$ & $\mathbf{n}$ & $\mathbf{X}^{\mathbf{2}}$ & sig \\
\hline \hline Total cover & 27 & 2.61 & 0.271 & 27 & 0.45 & 0.799 \\
\hline Nat. cover & 27 & 6.50 & $\mathbf{0 . 0 3 9}$ & 27 & 3.83 & 0.148 \\
\hline N-nat. cover & 27 & 1.21 & 0.547 & 27 & 1.09 & 0.581 \\
\hline Total richness & 27 & 6.99 & $\mathbf{0 . 0 3 0}$ & 27 & 0.59 & 0.745 \\
\hline Nat. richness & 27 & 4.05 & 0.132 & 27 & 0.27 & 0.875 \\
\hline N-nat. richness & 27 & 4.12 & 0.128 & 27 & 1.17 & 0.556 \\
\hline
\end{tabular}

P-values $<0.05$ are in bold type. Nat.: native species; N-nat.: non-native species.

In contrast, eleven years after the fire (Fig. 3), non-native species were found at the leeward site as well as at the windward site. Non-native graminoids, G. scabrum and $O$. vulgare were still indicators for windward control plots and Geranium species for leeward burnt plots. However, a number of new non-native species were found at the leeward site not particularly related to any treatment. All these species had covers under $1 \%$. 
Table 4. Number of Samples (n) Statistical Value (Z) and Significance (sig) for Wilcoxon Tests

\begin{tabular}{|c|c|c|c|c|c|c|c|c|c|}
\hline & \multicolumn{3}{|c|}{ Control } & \multicolumn{3}{c|}{ Low-Intensity } & \multicolumn{2}{c|}{ High-Intensity } \\
\cline { 2 - 10 } & $\mathbf{n}$ & $\mathbf{Z}$ & $\mathbf{s i g}$ & $\mathbf{n}$ & $\mathbf{Z}$ & $\mathbf{s i g}$ & $\mathbf{n}$ & $\mathbf{Z}$ & sig \\
\hline \hline Total cover & 6 & -1.43 & 0.154 & 12 & -3.01 & $\mathbf{0 . 0 0 3}$ & 9 & -2.50 & $\mathbf{0 . 0 1 2}$ \\
\hline Nat. cover & 6 & -1.57 & 0.116 & 12 & -2.59 & $\mathbf{0 . 0 1 0}$ & 9 & -2.52 & $\mathbf{0 . 0 1 2}$ \\
\hline N-nat. cover & 6 & -0.54 & 0.588 & 12 & -1.72 & 0.086 & 9 & -0.34 & 0.735 \\
\hline Total richness & 6 & -0.32 & 0.751 & 12 & -0.09 & 0.931 & 9 & -1.81 & 0.070 \\
\hline Nat. richness & 6 & -0.41 & 0.680 & 12 & -0.36 & 0.723 & 9 & -0.88 & 0.379 \\
\hline N-nat. richness & 6 & 0.00 & 1.000 & 12 & -0.60 & 0.546 & 9 & 1.70 & 0.090 \\
\hline
\end{tabular}

We repeated both DCAs including aspect as covariable to eliminate the variability created by this variable and see if fire intensity gained providence (data not shown). In addition, a Pearson correlation was used to asses if fire intensity was responsible for species composition variation among plots. We did not find a correlation (data not shown), so we cannot say that fire intensity has an effect on species composition. Other factors may be limiting and managing non-native species establishment.

\section{DISCUSSION}

The Canarian pine forest was heavily disturbed as a result of intense logging following the European colonization of the Canary Islands [36]. Large areas in Tenerife were reforested with $P$. canariensis during the last century [27], including the study sites. In addition, a considerable number of dirt roads cross the forest area. A high invasion rate could be expected associated to the anthropogenic disturbances $[13,37]$ and the possibility of propagule dispersal [38]. However, a small number of non-native species covered the area even after high-intensity fire and neither of the two most

DCA 3 years after fire

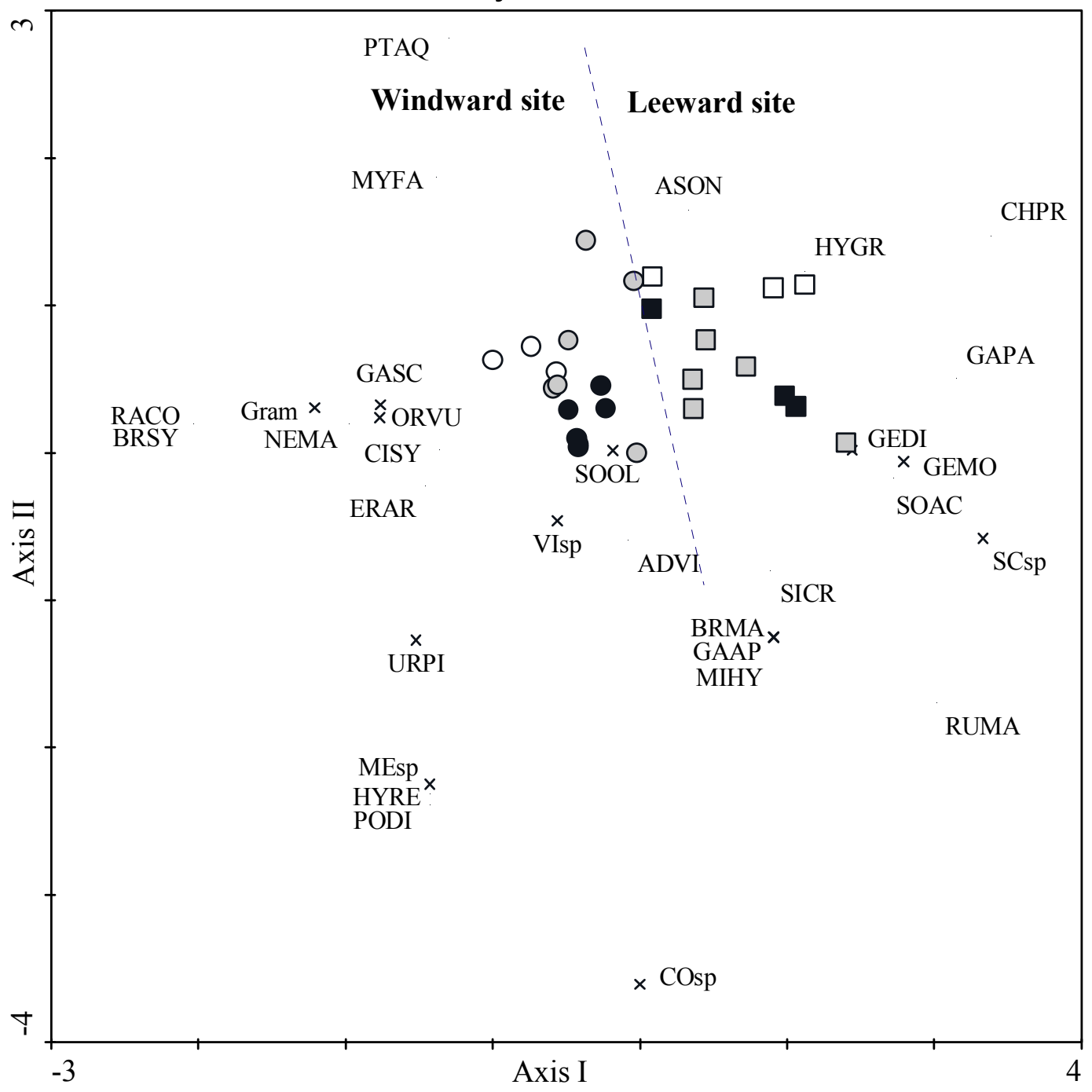

Fig. (2). DCA species and samples scores three years after fire. Circles are windward site plots and squares are leeward site plots. Empty figure in control, grey is low-intensity fire, black is high-intensity fire. Non-native or unknown species are marked with an x-mark. Nonnative species are in bold type. Native species are marked with a point. Species names are in the abbreviation list. 


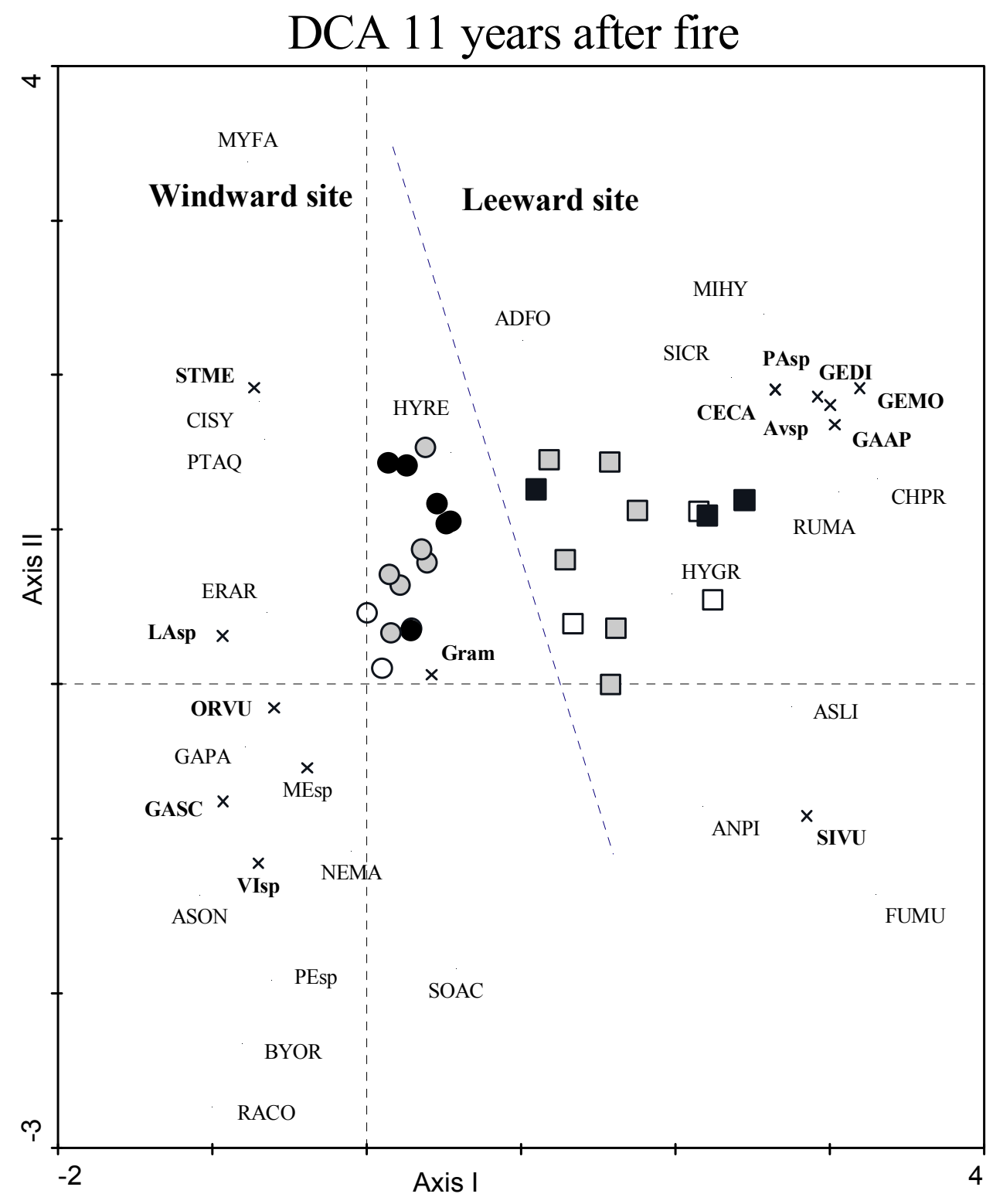

Fig. (3). DCA species and samples scores eleven years after fire. Circles are windward site plots and squares are leeward site plots. Empty figure in control, grey is low-intensity fire, black is high-intensity fire. Non-native or unknown species are marked with an x-mark. Nonnative species are in bold type. Native species are marked with a point. Species names are in the abbreviation list.

invasive non-native species in the pine forest (E. globulus and $S$. californica) were found in the study plots. Moreover, non-native species invasion seems to be not related with fire occurrence and intensity.

Each vegetation community is adapted to a different fire regime, exhibiting various adaptations that enable it to persist after fire [39]. Fire regimes have changed with human activities and this may reduce the native species advantage in recolonizing after fire. Moreover, fire has been reported to promote an explosion of non-native species population in the short-term [17, 18], which is especially detrimental after severe wildfire [2]. Our results contrasted with these findings, as no differences were found between fire severities or between burned and unburned plots. In concordance with our study, Kuenzi et al. [11] found similarly low non-native plant cover in low and high severely burned areas three years after fire. The cited authors explained the lower-than-expected success of non-native species, through the drought occurred during the study. The Canarian pine forest is mostly a nutrient-poor, dry ecosystem [40], where non-native species may not find proper conditions for establishing unless especially humid weather conditions (as 2006). This may explain the differences in non-native species composition at the leeward site (where water is more a limiting factor) between 1998 and 2006, 
which was accompanied with a higher cover and richness of native species as well. In this way, results suggest that fire itself is not influencing the rate of non-native species invasion, but other factors are more likely to have a larger influence on it: as precipitation, competition with native species or presence of propagules. However, all these variables have to be better studied to assess what their influence is.

Wildfires are recurrent in the Canary Islands, although their occurrence in the same area more than once within a 20-year period is rare [27]. Pinus canariensis is well adapted to high intensity fires [41] and understory vegetation may be adapted as well. Germination or growth of native species may be induced by high temperatures. The most common understory native species, Adenocarpus viscosus and Chamaecitysus proliferus, increased their cover after high intensity fire. The behavior of these species together with possible changes in soil characteristics after high-intensity fire [42] may be related to the reduction of non-native species in severely burned plots because of changes in availability of light, water and nutrients.

Most studies on the effect of fire in non-native plant invasions are short to middle-term, but vegetation dynamics are complex and long-term studies are necessary to observe changes in understory composition [43]. Species colonization after fire is dominated by early succesional species which are mostly annual or biennial and may disappear after pre-fire conditions recover. All non-native species in our study were therophyte or hemicryptophyte and the decrease in non-native species richness in severely burned areas eleven years after fire may be related to competition with native species as mentioned above.

Behavior of non-native species may be species specific [42]. Some species were more common in control plots while others were more common in burned plots. The same thing happened with regard to aspect. Thus, it is important to continue studying non-native species composition in the ecosystem, as the invasion of a new species could have completely different responses to a future fire.

\section{CONCLUSION}

Non-native species invasions are currently not a big problem in Tenerife pine forest. Only a few species have reached and colonized this ecosystem and they are always in low densities. We did not find a relation between fire and the invasion or expansion of these species, although it has some effect on general species composition. Non-native species seems to be less competitive under hydric stress, but they still build a soil seed bank and germinate when climatic conditions improve. Results suggest that some of the native understory plant species are adapted to high intensity fire and respond by increasing their cover after fire to the detriment of non-native species. Forest management with prescribed fire may not increase non-native species invasion as has occurred in other ecosystems.

\section{ACNKNOWLEDGEMENTS}

Plots and data three years after fire were part of a research project on fire effects and forest dynamics of the pine forest of Tenerife, which was supported by the Sección de Montes (Cabildo Insular de Tenerife). We thank
Ministerio de Ciencia e Innovacion (Spanish government) for granting the first author a FPU (Formación de Profesorado Universitario, AP2005-4736) pre-doctoral fellowship. We also thank José R. Arévalo, Silvia Fernández-Lugo and Gustavo Morales Morales for their help preparing the manuscript. Finally, I thank Larissa Yocom for correcting the English for this manuscript.

\section{ABBREVIATIONS}

$$
\begin{aligned}
& \text { ADVI = Adenocarpus viscosus (Willd.) Webb \& Berthel. } \\
& \text { ANPI = Andryala pinnatifida Aiton } \\
& \text { ASLI = Asterolinon linum-stellatum (L.) Duby in DC. } \\
& \text { ASON = Asplenium onopteris L. } \\
& \text { Avsp = Avena sp. (cf. barbata) } \\
& \mathrm{BRMA}=\text { Briza maxima } \mathrm{L} \text {. } \\
& \text { BRSY = Brachypodium sylvaticum (Huds.) P. Beauv. } \\
& \text { BYOR = Bystropogon origanifolius L'Hér. } \\
& \text { CECA = Centranthus calcitrapae (L.) Dufr. } \\
& \text { CISY = Cistus symphytifolius Lam. } \\
& \text { COsp = Conyza } \mathrm{sp} \text {. } \\
& \text { CHPR = Chamaecytisus proliferus (L. f.) Link } \\
& \text { ERAR = Erica arborea L. } \\
& \text { FUMU = Fumaria muralis Sonder ex Koch } \\
& \text { GAAP = Galium aparine L. } \\
& \text { GAPA = Galium parisiense L. } \\
& \text { GASC = Galium scabrum L. } \\
& \text { GEDI = Geranium dissectum } \mathrm{L} \text {. } \\
& \text { GEMO = Geranium molle L. } \\
& \text { Gram = Non-native graminoid } \\
& \text { HYGR = Hypericum grandifolium Choisy } \\
& \text { HYRE = Hypericum reflexum } \mathrm{L} . \mathrm{f} \text {. } \\
& \text { LAsp = Lthyrus sp. } \\
& \text { MEsp = Medicago } \mathrm{sp} \text {. } \\
& \text { MIHY = Micromeria hyssopifolia Webb \& Berthel. } \\
& \text { MYFA = Myrica faya Aiton } \\
& \text { NEMA = Neotinea maculata (Desf.) Stearn } \\
& \text { ORVU = Origanum vulgare L. } \\
& \text { PAsp = Papaver sp. } \\
& \text { PEsp = Pericallis sp. } \\
& \text { PODI = Polycarpaea divaricata (Aiton) Poir. } \\
& \text { PTAQ = Pteridium aquilinum (L.) Kuhn in Kerst. } \\
& \text { RACO = Ranunculus cortusifolius Willd. } \\
& \text { RUMA = Rumex maderensis Lowe } \\
& \text { SCsp }=\text { Scrophularia } \mathrm{sp} \text {. } \\
& \text { SICR = Sideritis cretica } \mathrm{L} \text {. } \\
& \text { SIVU = Silene vulgaris (Moench) Garcke }
\end{aligned}
$$


SOAC = Sonchus acaulis Dum. Cours.

SOOL = Sonchus oleraceus L.

STME = Stellaria media (L.) Vill.

URPI = Urospermum picroides (L.) Scop. ex F. W. Schmidt

VIsp $\quad=$ Vicia $\mathrm{sp}$.

\section{REFERENCES}

[1] Vitousek PM, D'Antonio CM, Loope LL, Westbrooks R. Biological invasions as global environmental change. Am Sci 1996; 84: 468-78.

[2] Hunter ME, Omi PN, Martinson EJ, Chong GW. Establishment of non-native plant species after wildfires: effects of fuel treatments, abiotic and biotic factors, and post-fire grass seeding treatments. Int J Wildland Fire 2006; 15; 271-81.

[3] Bataineh AL, Oswald BP, Bataineh MM, Williams HM, Coble DW. Changes in understory vegetation of a ponderosa pine forest in northern Arizona 30 years after a wildfire. For Ecol Manage 2006; 235: 283-94.

[4] Swope SM. Exotic plant invasions in relation to diversity, limiting resources and livestock grazing in Arizona grasslands. M.S. Thesis, School of Forestry, Flagstaff, AZ, Northern Arizona University 2003.

[5] Dietz H, Steinlein T, Ullmann I. Establishment of the invasive perennial herb Bunias orientalis L.: an experimental approach. Acta Oecol 1999; 20: 621-32

[6] Parker IM, Reichard SH. Critical issues in Invasion Biology for Conservation Science. In: Fiedler P, Kareiva P, Eds. Conservation Biology. New York: Chapman \& Hall 1998; pp. 283-305

[7] Levine JM, Vila M, D'Antonio CM, Dukes JS, Grigulis K, Lavorel S. Mechanisms underlying the impacts of exotic plant invasions. Proc Biol Sci 2003; 270: 775-81.

[8] Menke CA, Muir PS. Short-term influence of wildfire on canyon grassland plant communities and Spalding's catchfly, a threatened plant. Northwest Sci 2004; 78: 192-203.

[9] Turner MG, Romme WH, Gardener RH, Hargrove WW. Effects of fire size and pattern on early succession in Yellowstone National Park. Ecol Monogr 1997; 67: 411-33.

[10] 0Keeley JE, Lubin D, Fotheringham CJ. Fire and grazing impacts on plant diversity and alien plant invasions in the southern Sierra Nevada. Ecol Appl 2003; 13: 1355-74.

[11] Kuenzi AM, Fulé PZ, Sieg CH. Effects of fire severity and pre-fire stand treatment on plant community recovery after a large wildfire. For Ecol Manage 2008; 255: 855-65.

[12] Arévalo JR, Fernández-Palacios JM, Jiménez MJ, Gil P. The effect of fire intensity on the understory species composition of two Pinus canariensis reforested stands in Tenerife (Canary Islands). For Ecol Manage 2001; 148: 21-9.

[13] Huisinga KD, Laughlin DC, Fulé PZ, Springer JD, McGlone CM. Effects of an intense prescribed fire on understory vegetation in a mixed conifer forest. J Torrey Bot Soc 2005; 132: 590-601.

[14] Foxx TS. Vegetation succession after the La Mesa fire at Bandelier National Monument. In: Allen CD, Ed. Fire Effects in Southwestern Forests: Proceedings of the Second La Mesa Fire Symposium; 1994: Los Alamos, NM: SDA Forest Service, Rocky Mountain Forest and Range Experiment Station, Fort Collins, CO; 1996; pp. 47-69.

[15] Griffis KL, Crawford JA, Wagner MR, Moir WH. Understory response to management treatments in northern Arizona ponderosa pine forests. For Ecol Manage 2001; 146: 239-45.

[16] Wienk CL, Sieg CH, McPherson GR. Evaluating the role of cutting treatments, fire and soil seed banks in an experimental framework in ponderosa pine forests of the Black Hills, South Dakota. For Ecol Manage 2004; 192: 375-93.

[17] Floyd ML, Hanna D, Romme WH, Crews TE. Predicting and mitigating weed invasions to restore natural post-fire succession in Mesa Verde National Park, Colorado, USA. Int J Wildland Fire 2006; 15: 247-59.
[18] Crawford JA, Wahren CHA, Kyle S, Moir WH. Responses of exotic plant species to fires in Pinus ponderosa forests in northern Arizona. J Veg Sci 2001; 12: 261-8.

[19] Neary DG, Klopatek CC, DeBano LF, Ffolloitt PF. Fire effects on belowground sustainability: a review and synthesis. For Ecol Manage 1999; 122: 51-71.

[20] Ryan KC, Noste NV. Evaluating prescribed fires. In: Lotan JE, Kilgore BM, Fischer WC, Mutch RW, Eds. Ogden, UT. U.S. Department Of Agriculture, Forest Service, Intermountain Forest and Range Experiment Station 1985; pp. 230-8.

[21] Keeley JE. Ecological impacts of wheat seeding after a Sierra Nevada wildfire. Int J Wildland Fire 2004; 13: 73-8.

[22] Johnson M, Rew LJ, Maxwell BD, Sutherland S. The Role of Wildfire in the Establishment and Range Expansion of Nonnative Plant Species into Natural Areas. Bozeman, MT: Montana State University Center for Invasive Plant Management; 2006.

[23] Martín EJL, Marrero GMC, Zurita PN, Arechavaleta HM, Izquierdo ZI. Biodiversidad en gráficas. Especies silvestres de las Islas Canarias. Gobierno de Canarias: Consejería de Medio Ambiente y Ordenación Territorial 2005.

[24] Arechavaleta M, Martín JL. La perspectiva archipielágica: Canarias. In: Martín JL, Arechavaleta M, Borges PAV, Faria B, Eds. Top 100. Las 100 especies amenazadas prioritarias de gestión en la región europea biogeográfica de la Macaronesia, Consejería de Medio Ambiente y Ordenación Territorial, Gobierno de Canarias 2008; pp. 129-45.

[25] Nogales M, Rodríguez LJL, Marrero P. Ecological effects and distribution of invasive non-native mammals on the Canary Islands. Mammal Rev 2006; 36: 49-65.

[26] Silva L, Ojeda LE, Rodríguez LJL, Eds. Invasive Terrestrial Flora \& Fauna of Macaronesia. TOP 100 in Azores, Madeira and Canaries. Ponta Delgada: ARENA 2008.

[27] del Arco Aguilar MJ, Pérez de Paz PL, Rodríguez DO, Salas PM, Wildpret de La TW. Atlas Cartográfico de los Pinares Canarios II: Tenerife. Santa Cruz de Tenerife: Viceconsejería de Medio Ambiente y Conservación de la Naturaleza, Consejería de Política Territorial, Gobierno de Canarias 1992.

[28] Kämmer F. Klima und Vegetation auf Tenerife, besonders in Hinblick auf den Nebelniederschlag. Scr Geobot. 1974; 7: 1-78.

[29] Ceballos L, Ortuño F. Vegetación y flora forestal de las Canarias Occidentales. Santa Cruz de Tenerife: Excmo. Cabildo Insular de Tenerife 1976.

[30] Blanco A, Castroviejo M, Fraile JL, Gandullo JM, Muñoz LA, Sánchez PO. Estudio ecológico del Pino canario. Madrid: ICONA. Serie Técnica no. 6, 1989.

[31] Fernández-Palacios JM. Climatic responses of plant species on Tenerife (Canary Islands). J Veg Sci 1992; 3: 595-602.

[32] Izquierdo I, Martín JL, Zurita N, Arechavaleta M, Eds. Lista de especies silvestres de Canarias (hongos, plantas y animales terrestres) Consejería de Medio Ambiente y Ordenación Territorial, Gobierno de Canarias 2004.

[33] Green SB, Salkind NJ. Using SPSS for Windows and Macintosh: Analyzing and understanding data. $4^{\text {th }}$ ed. Upper Saddle River, NJ: Prentice Hall 2005.

[34] Hill MO, Gauch HG Jr. Detrended correspondence analysis: An improved ordination technique. Vegetatio 1980; 42: 47-58.

[35] ter Braak CJF, Šmilauer P. CANOCO Reference Manual and User's Guide to Canoco for Windows. Software for Canonical Community Ordination, version 4. Ithaca, NY: Centre for Biometry Wageningen (Wageningen, NL) and Microcomputer Power 1998.

[36] Parsons JJ. Human influences on the pine and laurel forests of the Canary Islands. Geogr Rev1981; 71: 253-271

[37] Klinger R, Underwood EC, Moore PE. The role of environmental gradients in non-native plant invasion into burnt areas of Yosemite National Park, California. Divers Distrib 2006; 12: 139-56.

[38] Pauchard A, Alaback, PB. Edge type defines alien plant species invasions along Pinus contorta burned, highway and clearcut forest edges. For Ecol Manage 2006; 223: 327-35.

[39] Agee JK. Fire Ecology of Pacific Northwest Forests. Washington D.C: Island Press 1993. 
[40] Autofocus [homepage on the internet] Pérez Martín JA, Flora de las Islas Canarias: Ecosistemas; 2009 [updated 2009; cited 2009 July]. Available from: http://www.autofocus.es/

[41] Climent J, Tapias R, Pardos JA, Gil L. Fire adaptations in the Canary Islands pine (Pinus canariensis). Plant Ecol 2004; 1: 18596.
$[42]$

Hebel CL, Smith JE, Cromack K Jr. Invasive plant species and soil microbial response to wildfire burn severity in the Cascade of Oregon. Appl Soil Ecol 2009; 42: 150-9.

[43] Korb JE, Covington WW, Fulé PZ. Sampling techniques influence understory plant trajectories after restoration: an example from ponderosa pine restoration. Restor Ecol 2003; 11: 504-15.

Received: July 30, 2009

(C) García-Domínguez and Fernández-Palacios; Licensee Bentham Open.

This is an open access article licensed under the terms of the Creative Commons Attribution Non-Commercial License (http://creativecommons.org/licenses/by$\mathrm{nc} / 3.0 /$ ) which permits unrestricted, non-commercial use, distribution and reproduction in any medium, provided the work is properly cited. 